\title{
HUNGARIAN BOOKS ON LINGUISTICS
}

Gábor Alberti - Ágota Fóris (eds): A mai magyar formális nyelvtudomány mühelyei [Workshops of current Hungarian formal linguistics]. Nemzeti Tankönyvkiadó, Budapest, 2007. 188 pp.

This volume is a collection of articles offering an introduction, for a wider audience, to current work of Budapest, Szeged, Debrecen and Pécs workshops of formal linguistics'formal' not only in the usual Chomskyan way but also in different alternative ways.

The book consists of three major parts. The first, and largest, part is devoted to Hungarian syntax. Tibor Laczkó and György Rákosi (Debrecen) give an extensive analysis of a mysterious Hungarian word, való (an adjectival participle derived from van 'be'), in an LFG framework. László Kálmán and Cecília Molnár (Budapest) discuss the problem of pronouns in teaching Hungarian syntax. Zoltán Bánréti (Budapest) intends to offer an insight into the connection of formal (generative) syntax with current researches in neurolinguistics and aphasia. Judit Farkas, Anna Medve and Ágnes Nagy (Pécs) outline the plan of a simplified Hungarian transformational generative syntax for teaching Hungarian as a mother tongue. Mónika Dóla and Judit Farkas (Pécs) extend this research to the area of teaching Hungarian as a foreign language.

There are two articles in the second part of the book, which deals with formal semantics. Márta Maleczki (Szeged) shows how to calculate, "compositionally", the meaning of basic Hungarian syntactic structures in a model-theoretic framework. The other article (by Gábor Alberti, Mónika Dóla, Györgyi Kántor, Judit Kleiber (Pécs) and Magdolna Ohnmacht (Szeged)) is intended to provide an insight to a new formal ("dynamic") discourse semantics called ReALIS, which is the abbreviation for REciprocal And Lifelong Interpretation System.

The third major topic of the volume is computational linguistics in Hungary. Attila Novák and Nóra Wenszky's paper on morphological parsers promises a quick insight into the work of Budapest computational linguists. Judit Kleiber shows the Pécs work in the area, which relies on the conviction that computational linguistics 
is worth returning from the nowadays wide-spread attitude characterized by "shallow parsing" to the pure theoretical (generative) linguistic basis.

The book helps specialists and students with a background in Hungarian syntax, formal semantics and computational linguistics to develop their knowledge on these areas. Workers in other disciplines will also use it to discover more about these exciting research areas in modern linguistics thanks to the authors who are leaders or seminal representatives of the research teams concerned.

Gábor Olaszy: Mássalhangzó-kapcsolódások a magyar beszédben [Consonant clusters in Hungarian speech]. Tinta Könyvkiadó, Budapest, 2007. 265 pp.

This is the first published summary on the acoustic structure of Hungarian consonant clusters. The book contains six chapters and an appendix.

The first chapter introduces the material and method of research. Four cluster types are discussed from CC to CCCCC. A word list was defined; each word represented one consonant cluster (e.g., labda 'ball'; ellentmondó 'contradictory'). Altogether 897 types of consonant clusters were analysed and discussed. The word list was recorded as read by five male and five female speakers. This recording was the target of the analysis. The sound files were semi-automatically labelled, i.e., voiced/voiceless markers and sound boundaries were added to the speech waveform and a phonemic transcription was also provided for each item. As it was impossible to include acoustic diagrams of all the words in the book, a homepage was developed where the acoustic diagrams of the whole word list are stored as uttered by one male and one female speaker (http://fonetika.nytud.hu/cccc). This speech database is an integral part of the book. The text of the book and the homepage material, taken together, provide the reader with complex information about Hungarian consonant clusters. The book contains numerous figures, showing expressively the structural changes observable inside the sounds of clusters. Computer-based support was used for the analysis and for making representative figures about the acoustic changes in clusters.

The second chapter discusses the basic cluster type in which two consonants make up the sound combination at hand. All possible CC clusters (373 types) are discussed. Duration characteristics, spectral features, and structural changes are detailed. Some examples of the results of the evaluation: in CC clusters the duration of both C's is shorter than the duration of the same consonants in intervocalic position; the complexity of articulatory movements is also reflected by the durations (less complex movements result in shorter duration and vice versa). In the most complex cases additional sound elements appear in the waveform around the meeting point of the two consonants (spirantisation, schwa element, coarticulatory silent phase, etc.).

The third chapter discusses CCC clusters. 445 types of such sound combinations are investigated. The author compares these clusters with CC ones, and describes the changes (if any). The shortening tendency continues, i.e., the consonants have shorter duration than in $\mathrm{CC}$ clusters. An interesting result is the frequency distribution of consonants occurring as building elements of the CCC clusters. The most frequent sound is the tremulant, but it occurs only in initial and final position.

In chapter four, the author turns to CCCC clusters; 74 types are discussed. The shortening tendency ceases to apply in these clusters: the sound durations are similar to those in CCC clusters. To explain this phenomenon, the author hypothesises that the articulation of four consonants is so complicated that one cannot do it as automatically 
as in CC and in CCC cases. As to the most frequent building element, it is also the tremulant: it occurs in initial and final positions as seen earlier. Chapter five is a short one, containing the description of CCCCC clusters. These clusters are very rare in speech, altogether five types were found.

In chapter six, the author introduces the accompanying homepage (mentioned above) and the interactive program that allows searching for any cluster in the speech database. Two options are available: search on the sound level and on the text level. The following acoustic features can be displayed: waveform with sound boundaries, spectrogram, and intensity pattern. It is also possible to listen to the examples. The user can measure formant frequency and intensity values and compare the acoustic structures of pairs of words.

The appendix contains lists of frequency distribution for all cluster types, lists with detailed duration values, and alphabetical lists according to the position of the consonant inside the cluster.

Christopher Piñón - Szilárd Szentgyörgyi (eds): Approaches to Hungarian. Volume 10. Papers from the Veszprém conference. Akadémiai Kiadó, Budapest, 2008. 249 pp.

This is volume ten of the series Approaches to Hungarian, which contains eleven papers that were originally presented at the Seventh International Conference on the Structure of Hungarian (ICSH-7) held on 29-31 May 2005 at the (former) University of Veszprém (Veszprémi Egyetem), now known as the University of Pannonia (Pannon Egyetem). The eleven papers of this volume form a subcollection of the collection of papers presented at ICSH-7. The Approaches series has been based on corresponding ICSH conferences since volume four: volume four on ICSH-1 in Bloomington in 1992, volume five on ICSH-2 in Szeged in 1994, volume six on ICSH-3 in Amsterdam in 1996, volume seven on ICSH-4 in Pécs in 1998, volume eight on ICSH-5 in Budapest in 2001, and volume nine on ICSH-6 in Düsseldorf in 2002.

The eleven contributions to this volume, which are ordered alphabetically, largely address problems in (morpho)syntax, semantics, and phonology. Anna Asbury proposes that Hungarian case suffixes and postpositions both be subsumed under the same morphosyntactic category $\mathrm{P}$, pointing out that these two traditional categories cannot be reliably distinguished from each other on either semantic or morphosyntactic grounds. Katalin É. Kiss revisits and reconsiders her long-standing conjecture that the Hungarian VP is flat, suggesting that a Minimalist approach may make the postulation of a hierarchical VP more plausible than it had appeared earlier. Beáta Gyuris investigates the puzzling phenomenon of how postverbal stressed quantificational expressions can have wide scope with respect to preverbal operators in Hungarian, arguing that such expressions are topics and signal a conjunction of assertive speech acts. Scott Jackson offers another perspective on the same problem, proposing that a processing-based account sheds light on this phenomenon and that the processing system can relieve the grammatical system of extra explanatory burden. Tibor Laczkó examines the binding properties of the external argument in Hungarian passive participial constructions in depth, concluding that a dual solution involving suppression or the presence of PRO is required. Krisztina Polgárdi argues that a loose CV approach making use of trochaic proper government offers a more elegant account of lexical degemination in Hungarian than the standard Government Phonology approach, which postulates more elaborate syllable structure. György Rákosi and Tibor Laczkó provide a battery of arguments for 
treating agreement-marked infinitival constructions in Hungarian as categorially verbal and not nominal, against certain earlier proposals. Catherine Ringen discusses the similarities and differences in the voicing of word-initial stops in Hungarian, Russian, Swedish, and Turkish, reporting on the results of experiments concerning the distinction between passive and active voicing. Péter Siptár examines various patterns of hiatus resolution in Hungarian and proposes how to account for them in Optimality Theory. Enikö Tóth investigates mood selection in Hungarian complement clauses, in particular, how the semantic character of the matrix predicate (e.g., factive versus semifactive, affirmative or not) predicts or at least motivates the choice of indicative or non-indicative mood in its complement clause. Finally, Zara Wanlass examines variation in Hungarian vowel harmony by searching for a set of vacillating word stems in two online corpora, concluding that there are significant differences in vacillation even among vacillating word stems.

Contents: Anna Asbury: Marking of semantic roles in Hungarian morphosyntax; Katalin É. Kiss: The structure of the Hungarian VP revisited; Beáta Gyuris: Stylistic postposing or something else; Scott Jackson: The prosody-scope relation in Hungarian; Tibor Laczkó: On binding, empty categories, and morphosyntactic processes in "passive" participial constructions; Krisztina Polgárdi: Geminates and degemination in Hungarian: A loose CV analysis; György Rákosi - Tibor Laczkó: On the categorial status of agreement-marked infinitives in Hungarian; Catherine O. Ringen: Crosslinguistic differences and similarities in stop voicing; Péter Siptár: Hiatus resolution in Hungarian: An optimality theoretic account; Enikő Tóth: Mood selection in complement clauses; Zara Wanlass: Evidence from online corpora for variation in Hungarian vowel harmony. 